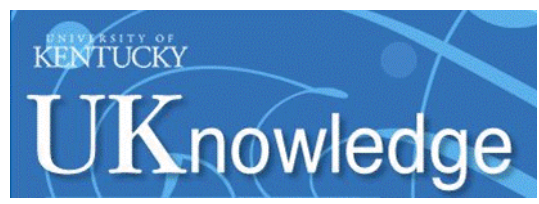

University of Kentucky UKnowledge

\title{
9-15-2017
}

\section{Design, Synthesis, and Biological Activity of 5'- Phenyl-1,2,5,6-tetrahydro-3,3'-bipyridine Analogues as Potential Antagonists of Nicotinic Acetylcholine Receptors}

\author{
Yafei Jin \\ University of Michigan - Ann Arbor \\ Xiaoqin Huang \\ University of Kentucky \\ Roger L. Papke \\ University of Florida \\ Emily M. Jutkiewicz \\ University of Michigan - Ann Arbor
}

See next page for additional authors

Right click to open a feedback form in a new tab to let us know how this document benefits you. Follow this and additional works at: https://uknowledge.uky.edu/ps_facpub

Part of the Medicinal-Pharmaceutical Chemistry Commons, and the Pharmacy and Pharmaceutical Sciences Commons 
Design, Synthesis, and Biological Activity of 5'-Phenyl-1,2,5,6-tetrahydro-3,3'bipyridine Analogues as Potential Antagonists of Nicotinic Acetylcholine Receptors

Digital Object Identifier (DOI)

https://doi.org/10.1016/j.bmcl.2017.08.025

Notes/Citation Information

Published in Bioorganic \& Medicinal Chemistry Letters, v. 27, issue 18, p. 4350-4353.

(c) 2017 Elsevier Ltd. All rights reserved.

This manuscript version is made available under the CC-BY-NC-ND 4.0 license https://creativecommons.org/licenses/by-nc-nd/4.0/.

The document available for download is the author's post-peer-review final draft of the article.

Authors

Yafei Jin, Xiaoqin Huang, Roger L. Papke, Emily M. Jutkiewicz, Hollis D Showalter, and Chang-Guo Zhan 


\title{
Design, Synthesis, and Biological Activity of $5^{\prime}$-Phenyl-1,2,5,6- tetrahydro-3,3' -bipyridine Analogues as Potential Antagonists of Nicotinic Acetylcholine Receptors
}

\author{
Yafei Jin ${ }^{1}$, Xiaoqin Huang ${ }^{2}$, Roger L. Papke ${ }^{3}$, Emily M. Jutkiewicz ${ }^{4}$, Hollis D. Showalter ${ }^{1}{ }^{*}$, \\ and Chang-Guo Zhan ${ }^{2, *}$ \\ ${ }^{1}$ Department of Medicinal Chemistry and Vahlteich Medicinal Chemistry Core, University of \\ Michigan, Ann Arbor, MI 48109 \\ 2Department of Pharmaceutical Sciences and Molecular Modeling and Biopharmaceutical Center, \\ College of Pharmacy, University of Kentucky, 789 South Limestone Street, Lexington, KY 40536 \\ ${ }^{3}$ Department of Pharmacology and Therapeutics, University of Florida, Gainesville, FL 32610 \\ ${ }^{4}$ Department of Pharmacology, University of Michigan Medical School, Ann Arbor, MI 48109
}

\begin{abstract}
Starting from a known non-specific agonist (1) of nicotinic acetylcholine receptors (nAChRs), rationally guided structural-based design resulted in the discovery of a small series of $5^{\prime}$ phenyl-1,2,5,6-tetrahydro-3,3'-bipyridines ( $\mathbf{3 a}-\mathbf{3 e}$ ) incorporating a phenyl ring off the pyridine core of $\mathbf{1}$. The compounds were synthesized via successive Suzuki couplings on a suitably functionalized pyridine starting monomer 4 to append phenyl and pyridyl substituents off the 3 and 5-positions, respectively, and then make subsequent modifications on the flanking pyridyl ring to provide target compounds. Compound $\mathbf{3 a}$ is a novel antagonist which is highly selective for a $3 \beta 4 \mathrm{nAChR}\left(K_{\mathrm{i}}=123 \mathrm{nM}\right)$ over the $\alpha 4 \beta 2$, and $\mathrm{a} 7$ receptors.
\end{abstract}

\section{Graphical Abstract}

Structure-based molecular design starting from a known non-specific agonist (1) of nicotinic acetylcholine receptors has generated a novel antagonist (3a) that is a reasonably potent and highly selective antagonist for the $a 3 \beta 4$ receptor over $\alpha 4 \beta 2$ and $\alpha 7$.

\footnotetext{
*Corresponding authors. showalh@umich.edu (H.D.S.) or zhan@uky.edu (C.-G.Z.).

Supplemental data

Supplementary data (details of the chemical syntheses and assays performed) associated with this article can be found, in the online version, at http://dx.doi...

Publisher's Disclaimer: This is a PDF file of an unedited manuscript that has been accepted for publication. As a service to our customers we are providing this early version of the manuscript. The manuscript will undergo copyediting, typesetting, and review of the resulting proof before it is published in its final citable form. Please note that during the production process errors may be discovered which could affect the content, and all legal disclaimers that apply to the journal pertain.
} 


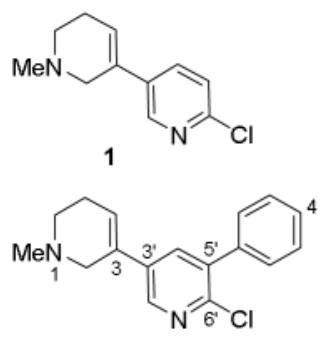

2

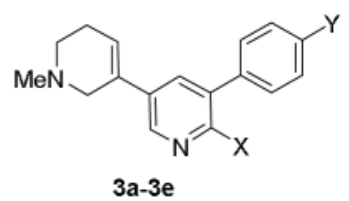

a: $X=F ; Y=H$

b: $X=F ; Y=F$

c: $X=F ; Y=C l$

d: $X=F ; Y=\mathrm{SO}_{2} \mathrm{CH}_{3}$

e: $X=O H ; Y=H$

\section{Introduction}

Nicotinic acetylcholine receptors (nAChRs) are a family of well-studied ligand-gated ion channels that directly mediate fast signal transmission at chemical synapses through binding with neurotransmitter molecules.[1-5] This family of receptors consists of various subtypes, including a $3 \beta 4$, $\alpha 4 \beta 2$, and $a 7$ etc. in the central nervous system (CNS). Abnormal openingclosing of these ion channels contributes to neurodegenerative disorders, resulting in several severe diseases, including Alzheimer's disease, Parkinson's disease, dyskinesias, Tourette's syndrome, schizophrenia, attention deficit disorder, anxiety, pain, and nicotine addiction.[2, 6-13] Hence, there is a need to develop subtype-selective agonists/antagonists of nAChRs as potential therapeutic agents.

For the rational design of potent agonists or antagonists of nAChRs, one first needs to understand the detailed three-dimensional (3D) structures and physiological functions of $\mathrm{nAChRs}$. According to various reported X-ray diffraction and molecular modeling studies, [14-22] a ligand binding to the $\mathrm{nAChR}$ receptor in the acetylcholine (ACh)-binding site can be either an agonist or an antagonist, because the receptor can exist in the open- or closedchannel state.[19] An agonist can more favorably bind with the open-channel state of the receptor, whereas an antagonist can more favorably bind with the closed-channel state.[19] Various agonists and antagonists of nAChRs have been reported in the literature. However, compared to agonists, there are relatively few reported antagonists of nAChRs, particularly for $a 3 \beta 4, \alpha 4 \beta 2$, and $a 7$ subtypes.[6, 10, 13, 23] We are particularly interested in subtypespecific antagonists of $\alpha 3 \beta 4$ and $\alpha 4 \beta 2 \mathrm{nAChRs}$, and toward that end set out to design and synthesize new antagonists of these nAChRs as potential treatments for drug addiction.

In this study, we tested the feasibility of converting a known agonist to an antagonist by modifying the agonist structure. Our strategy is based on a previous demonstration[19] that an agonist may bind to both the open- and closed-channel states of the nAChR, but with a relatively higher binding affinity to the open state. If we could appropriately modify the agonist structure in such a way that it no longer fits the binding pocket of the open-channel state, but still fits the binding pocket of the closed state, then it could become an antagonist.

Compound 1, depicted in Figure 1, is a known non-specific agonist of nAChRs in rat brain membranes (with $K_{\mathrm{d}}=\sim 2.2 \mathrm{nM}$ ). [24, 25] According to our modeling inspection using the $3 \mathrm{D}$ model of the open-channel structures[19] of a $3 \beta 4, \alpha 4 \beta 2$, and a $7 \mathrm{nAChRs,} \mathrm{compound} 2$ (modified from compound $\mathbf{1}$ with a phenyl ring attached to the pyridine ring) would not fit 
the binding pocket of the open-channel state of any of the above three receptors. But it might still fit the binding pocket of the closed-channel state. To test this hypothesis, we targeted the synthesis of five $5^{\prime}$-phenyl-1,2,5,6-tetrahydro-3,3'-bipyridine analogues (3a-3e, Figure 1) related to compound 2 to determine whether we could identify a new antagonist. Our decision to focus initially on $2^{\prime}$-fluoropyridines rather than $2^{\prime}$-chloropyridine 2 related to their ease of synthesis (vide infra).

Our strategy toward constructing the novel $5^{\prime}$-phenyl-1,2,5,6-tetrahydro-3, $3^{\prime}$-bipyridine core was to carry out successive Suzuki couplings on a suitably functionalized pyridine starting monomer to append desired aromatic substituents at the 3- and 5-positions, and then make subsequent modifications on the flanking 5-pyridyl ring to provide target compounds (Scheme 1). Our decision to start with the core 5-bromo-2-fluoropyridine-3-boronic acid (4) rather than the 2-chloro congener (toward securing analogues of 2) was predicated on the assumption that the second-stage Suzuki coupling would have been highly unselective. The initial coupling of commercially available boronic acid $\mathbf{4}$ with phenyl halides (iodo, bromo) to provide 3-(phenyl-substituted)pyridyl intermediates 5a-5d was carried out by a modification of a literature procedure [26]. Yields were poor to modest $(16-37 \%)$ with TLC showing the presence of multiple products, likely due to competitive palladiumcatalyzed hetero- and homo bimolecular coupling side reactions. A second stage Suzuki coupling of 5a-5d with pyridine-3-boronic acid under similar conditions proceeded much more cleanly to give $3,3^{\prime}$-bipyridine products $\mathbf{6 a - 6 d}$ in $71-93 \%$ yield. Two-step elaboration of these to target 1-methyl-1,2,5,6-tetrahydro-3,3'-bipyridine derivatives $\mathbf{3 a}-\mathbf{3 d}$ was achieved by following a literature procedure with close precedence [27]. Thus, treatment of $\mathbf{6 a}-\mathbf{6 d}$ with excess iodomethane in acetone resulted in selective methylation of the flanking pyridine ring to give $\mathbf{7 a}-\mathbf{7 d}$ in $72-100 \%$ yields. Subsequent reduction of these with sodium borohydride in ethanol then gave target compounds $\mathbf{3 a}-\mathbf{3 d}$ in $35-85 \%$ yields as free bases. These were then converted to hydrochloride salts for biological testing. Further modification of 3a with concentrated $\mathrm{HCl}$ utilized a literature procedure [28] to provide $6^{\prime}$-pyridinol congener $3 \mathbf{e}$ in $53 \%$ yield. Complete experimental procedures can be found in Supplemental Materials.

Calculated lipophilicity $(\operatorname{cog} P$ ), topological polar surface area (TPSA), and $\log B$ B-derived values provide information as to the potential of a compound for development as a pharmacotherapy for treating CNS disorders. These molecular descriptors were calculated for compounds 1, 2 3a-3e, as well as reference compounds nicotine and epibatidine (Table 1). In general, successful drugs used for treating CNS disorders have a $\operatorname{cog} P$ in the range $2-$ 4[29], TPSA less than $76 \AA$ [30] and $\log B B$ greater than $-1[31]$. All the compounds have clogP values $(2.08-4.04)$ within the range of CNS drugs, and run higher than the reference compounds nicotine and epibatidine. TPSA values $(16.1-58.6 \AA)$ and $\log B \mathrm{~B}$ values $(-0.38$ - 0.51) also meet the criteria of successful CNS drugs and except for $\mathbf{3 d}$ and $\mathbf{3 e}$ are higher than for the reference compounds $(0.04-0.06)$. All compounds have molecular weight $(<$ 400 daltons) that predict for good BBB penetration.

Of the five analogues (3a-3e) synthesized, 3a should be the most selective according to our previously reported molecular modeling and docking protocols.[19] This is because the modeling suggested that compound 3a can reasonably fit the binding pocket of the closed- 
channel state of a $3 \beta 4 \mathrm{nAChR}$, but not a $4 \beta 2$ or a $7 \mathrm{nAChR}$. None of these analogues appeared to fit the binding pocket of the open-channel state of any receptor examined (a $3 \beta 4$, $\mathbf{a} 4 \beta 2, \mathbf{a} 7)$. Hence, we proposed that compound $\mathbf{3 a}$ should be a selective antagonist of the a $3 \beta 4$ receptor. In the modeled binding structure of a $3 \beta 4 \mathrm{nAChR}$ with compound $\mathbf{3 a}$ (depicted in Figure 2), 3a stays on the interface between an a 3 subunit and a $\beta 4$ subunit in the usual agonist-binding site, with the protonated amine group of $\mathbf{3 a}$ interacting with the aromatic residues a Y93 (i.e., Y93 residue of the a 3 subunit), aY190, aW149, and $\beta$ W54 (i.e., W5 residue of the $\beta 4$ subunit). The $\mathrm{F}$ atom of $\mathbf{3 a}$ is close to the aromatic sides of aY197 and aW149. The phenyl ring of 3a is packed with the hydrophobic side chains of residues $\beta$ I108, $\beta$ L116, and $\beta$ L118 from $\beta 4$ subunit and, hence, any hydrophilic substitution on the $p$ - or $m$-position of the phenyl ring would be incompatible with the hydrophobic residues nearby.

The insights from molecular modeling were tested by carrying out electrophysiological experiments on compound 3a with a $3 \beta 4$, a $4 \beta 2$, and a 7 nAChRs using OpusXpress 6000A (Molecular Devices, Union City, CA), as we had done previously.[18, 32] OpusXpress is an integrated system that provides automated impalement and voltage clamp of up to eight oocytes in parallel (see Supplementary Information for complete experimental methods). First, we tried to detect possible agonist activity of compound $\mathbf{3 a}$ at a concentration of 100 $\mu \mathrm{M}$ for $\mathrm{a} 3 \beta 4,30 \mu \mathrm{M}$ for $\mathrm{a} 4 \beta 2$, and $60 \mu \mathrm{M}$ for $\mathrm{a} 7$ as compared with $100 \mu \mathrm{M}$ for acetylcholine $(\mathrm{ACh})$ as a control response. The data were normalized to the corresponding control ACh responses, showing no significant agonist activity for any of the receptors tested.

Further, electrophysiological experiments were performed to test the antagonist activity against the $\mathrm{nAChR}$ receptors with $\mathrm{ACh}$ at the same concentrations of the three receptors specified above. The data revealed that at a concentration of $100 \mu \mathrm{M}$, compound 3a significantly antagonized the a $3 \beta 4$ receptor, but showed no significant antagonist activity against the $a 4 \beta 2$ or a 7 receptors. With this finding, we ran a dose-response curve for compound 3a against the a $3 \beta 4$ receptor at $100 \mu \mathrm{M}$ ACh, calculating an $\mathrm{IC}_{50}=20 \pm 1 \mu \mathrm{M}$ (Figure 3). Hence, our data show that structural modification of the known agonist $\mathbf{1}$ has indeed resulted in the discovery of an a $3 \beta 4$ antagonist (3a) in vitro.

It should be noted that, in general, $\mathrm{s}$ a generated $\mathrm{IC}_{50}$ value is dependent on the substrate (ACh in this study) concentration [S] used in the assay. The higher the substrate concentration compared to the protein-substrate binding affinity $\left(K_{\mathrm{d}} \approx K_{\mathrm{m}}\right)$, the larger the $\mathrm{IC}_{50}$ value. But the $\mathrm{IC}_{50}$ value can be converted to an inhibition constant $\left(K_{\mathrm{i}}\right)$, which is independent of the substrate concentration. It was reported[6] that $K_{\mathrm{d}}=619.63 \mathrm{nM}$ for ACh binding with a $3 \beta 4 \mathrm{nAChR}$. Hence, based on the well-known relationship between the $\mathrm{IC}_{50}$ and $K_{\mathrm{i}}$ for a competitive antagonist/inhibitor,

$$
\mathrm{IC}_{50}=\left(1+[\mathrm{S}] / K_{\mathrm{m}}\right) K_{\mathrm{i}} \approx\left(1+[\mathrm{S}] / K_{\mathrm{d}}\right) K_{\mathrm{i}},
$$


Using this equation, this computes to $\mathrm{IC}_{50} \approx 162 K_{\mathrm{i}}$ for the a $3 \beta 4 \mathrm{nAChR}$ antagonist, assuming competitive antagonism in our assays using $[\mathrm{S}]=100 \mu \mathrm{M}$. So, $K_{\mathrm{i}}=\sim 123 \mathrm{nM}$ for compound 3a against a $3 \beta 4 \mathrm{nAChR}$.

In conclusion, we have used structure-based design on a known non-specific agonist (1) of the nicotinic acetylcholine receptor to generate a novel antagonist (3a) that is a reasonably potent and highly selective antagonist for the $\alpha 3 \beta 4$ receptor over $a 4 \beta 2$ and $\alpha 7$. Future studies will detail ongoing studies of $\mathbf{3 a}$ and other compounds of this series, including in vivo evaluation.

\section{Supplementary Material}

Refer to Web version on PubMed Central for supplementary material.

\section{Acknowledgments}

This research was supported in part by the National Science Foundation (NSF grant CHE-1111761), and the National Institutes of Health (NIH grants DA035552, DA032910, DA041115, GM057481, UL1TR001998, and T32-DA007268), and the University of Michigan Tobacco Research Network. We thank Clare Stokes for conducting the oocyte experiments.

\section{References}

1. Hogg RC, Bertrand D. Neuroscience. What genes tell us about nicotine addiction. Science. 2004; 306:983-985. [PubMed: 15528431]

2. Liu Z, Neff RA, Berg DK. Sequential interplay of nicotinic and GABAergic signaling guides neuronal development. Science. 2006; 314:1610-1613. [PubMed: 17158331]

3. Lape R, Colguhoun D, Sivilotti LG. On the nature of partial agonism in the nicotinic receptor superfamily. Nature. 2008; 454:722-727. [PubMed: 18633353]

4. Brannigan G, LeBard DN, Hénin J, Eckenhoff R, Klein ML. Multiple binding sites for the general anesthetic isoflurane identified in the nicotinic acetylcholine receptor transmembrane domain. Proc Natl Acad Sci USA. 2010; 107:14122-14127. [PubMed: 20660787]

5. Mazzaferro S, Bermudez I, Sine SM. a $4 \beta 2$ Nicotinic Acetylcholine Receptors: RELATIONSHIPS BETWEEN SUBUNIT STOICHIOMETRY AND FUNCTION AT THE SINGLE CHANNEL LEVEL. J Biol Chem. 2017; 292:2729-2740. [PubMed: 28031459]

6. Zaveri N, Jiang F, Olsen C, Polgar W, Toll L. Novel alpha3beta4 nicotinic acetylcholine receptorselective ligands. Discovery, structure-activity studies and pharmacological evaluation. J Med Chem. 2010; 53:8187-8191. [PubMed: 20979364]

7. Farhat SM, Ahmed T. Neuroprotective and Neurotoxic Implications of a 7 Nicotinic Acetylcholine Receptor and A $\beta$ Interaction: Therapeutic Options in Alzheimer's Disease. Curr Drug Targets. 2017 Epub ahead of print: Oct. 5, 2016.

8. Corradi J, Bouzat C. Understanding the Bases of Function and Modulation of a 7 Nicotinic Receptors: Implications for Drug Discovery. Mol Pharmacol. 2016; 90:288-299. [PubMed: 27190210]

9. Onajole OK, Vallerini GP, Eaton JB, Lukas RJ, BD, Caldarone BJ, Kozikowski AP. Synthesis and Behavioral Studies of Chiral Cyclopropanes as Selective a 4 $\beta 2$-Nicotinic Acetylcholine Receptor Partial Agonists Exhibiting an Antidepressant Profile. Part III. ACS Chem Neurosci. 2016; 7:811822. [PubMed: 27035276]

10. Ondachi PW, Castro AH, Luetje CW, Wageman CR, Marks MJ, Damaj MI, Mascarella SW, Navarro HnA, Carroll FI. Synthesis, Nicotinic Acetylcholine Binding, and in Vitro and in Vivo Pharmacological Properties of 2' -Fluoro-(carbamoylpyridinyl)deschloroepibatidine Analogues. ACS Chem Neurosci. 2016; 7:1004-1012. [PubMed: 27166021] 
11. Cippitelli A, Schoch J, Debevec G, Brunori G, Zaveri NT, Toll L. A key role for the N/OFQ-NOP receptor system in modulating nicotine taking in a model of nicotine and alcohol coadministration. Sci Rep. 2016; 6:26594. doi:26510.21038/srep26594. [PubMed: 27199205]

12. Zaveri NT, Bertrand S, Yasuda D, Bertrand D. Functional characterization of AT-1001, an a $3 \beta 4$ nicotinic acetylcholine receptor ligand, at human $a 3 \beta 4$ and $a 4 \beta 2 \mathrm{nAChR}$. Nicotine Tob Res. 2015; 17:361-367. [PubMed: 25180076]

13. Muldoon PP, Jackson KJ, Perez E, Harenza JL, Molas S, Rais B, Anwar H, Zaveri NT, Maldonado R, Maskos U, McIntosh JM, Dierssen M, Miles MF, Chen X, De Biasi M, Damaj MI. The a 3ß4* nicotinic ACh receptor subtype mediates physical dependence to morphine: mouse and human studies. Br J Pharmacol. 2014; 171:3845-3857. [PubMed: 24750073]

14. Celie PHN, Rossum-Fikkert SE, Dijk WJ, Brejc K, Smit AB, Sixma TK. Nicotine and carbamylcholine binding to nicotinic acetylcholine receptors as studied in AChBP crystal structures. Neuron. 2004; 41:907-914. [PubMed: 15046723]

15. Hansen SB, Sulzenbacher G, Huxford T, Marchot P, Taylor P, Bourne Y. Structures of Aplysia AChBP complexes with nicotinic agonists and antagonists reveal distinctive binding interfaces and conformation. The EMBO J. 2005; 24:3635-3646. [PubMed: 16193063]

16. Huang X, Zheng F, Crooks PA, Dwoskin LP, Zhan CG. Modeling multiple species of nicotine and deschloroepibatidine interacting with $\mathrm{a} 4 \mathrm{~b} 2$ nicotinic acetylcholine receptor: from microscopic binding to phenomenological binding affinity. J Am Chem Soc. 2005; 127:14401-14414. [PubMed: 16218635]

17. Huang X, Zheng F, Chen X, Crooks PA, Dwoskin LP, Zhan CG. Modeling subtype-selective agonists binding with a4b2 and a7 nicotinic acetylcholine receptors: Effects of local binding and long-range electrostatic interactions. J Med Chem. 2006; 49:7661-7674. [PubMed: 17181149]

18. Huang X, Zheng F, Stokes C, Papke RL, Zhan CG. Modeling binding modes of alpha7 nicotinic acetylcholine receptor with ligands: the roles of Gln117 and other residues of the receptor in agonist binding. J Med Chem. 2008; 51:6293-6302. [PubMed: 18826295]

19. Huang X, Zheng F, Zhan CG. Modeling Differential Binding of a4b2 Nicotinic Acetylcholine Receptor with Agonists and Antagonists. J Am Chem Soc. 2008; 130:16691-16696. [PubMed: 19554732]

20. Morales-Perez CL, Noviello CM, Hibbs RE. X-ray structure of the human a $4 \beta 2$ nicotinic receptor. Nature. 2016; 538:411-415. [PubMed: 27698419]

21. Kouvatsos N, Giastas P, Chroni-Tzartou D, Poulopoulou C, Tzartos SJ. Crystal structure of a human neuronal nAChR extracellular domain in pentameric assembly: Ligand-bound a 2 homopentamer. Proc Natl Acad Sci USA. Aug 23; 2016 113(34):9635-9640. [PubMed: 27493220]

22. Nayak TK, Chakraborty S, Zheng W, Auerbach A. Nature Commun. 2016; 7:11352. doi: 11310.11038/ncomms11352. [PubMed: 27101778]

23. Beard E, Shahab L, Cummings DM, Michie S, West R. New Pharmacological Agents to Aid Smoking Cessation and Tobacco Harm Reduction: What Has Been Investigated, and What Is in the Pipeline? CNS Drugs. 2016; 30:951-983. [PubMed: 27421270]

24. Radl S, Hezky P, Hafner W, Budesinsky M, Hejnova L. Synthesis and Binding Studies of Some Epibatidine Analogues. Bioorg Med Chem Lett. 2000; 10:55-58. [PubMed: 10636243]

25. Radl S, Hafner W, Budesinsky M, Hejnova L, Krejci I. Synthesis, Analgesic Activity, and Binding Properties of Some Epibatidine Analogs with a Tropine Skeleton. Arch Pharm Pharm Med Chem. 2000; 333:167-174.

26. Hynes, J., De Lucca, GV., Wu, H. Imidazopyridine and imidazopyrazine compounds useful as kinase inhibitors. Bristol-Myers Squibb Company; USA: 2012. p. 70pp

27. Radl S, Hafner W, Budesinsky M, Hejnova L, Krejci I. Synthesis, analgesic activity, and binding properties of some epibatidine analogs with a tropine skeleton. Arch Pharm (Weinheim, Ger). 2000; 333:167-174.

28. Sutherland A, Gallagher T. Versatile synthesis of 3,5-disubstituted 2-fluoropyridines and 2pyridones. J Org Chem. 2003; 68:3352-3355. [PubMed: 12688820]

29. Carroll FI. Epibatidine structure-activity relationships. Bioorg Med Chem Lett. 2004; 14:18891896. [PubMed: 15050621] 
30. Carroll FI. Epibatidine analogs synthesized for characterization of nicotinic pharmacophores-a review. Heterocycles. 2009; 79:99-120. [PubMed: 25530665]

31. Carroll FI, Lee JR, Navarro HA, Brieaddy LE, Abraham P, Damaj MI, Martin BR. Synthesis, Nicotinic Acetylcholine Receptor Binding, and Antinociceptive Properties of 2-exo-2-(2' -

Substituted-3' -phenyl-5' -pyridinyl)-7-azabicyclo [2.2.1] heptanes. Novel Nicotinic Antagonist. J Med Chem. 2001; 44:4039-4041. [PubMed: 11708907]

32. Papke RL, Bagdas D, Kulkarni AR, Gould T, AlSharari SD, Thakur GA, Damaj MI. The analgesiclike properties of the alpha7 nAChR silent agonist NS6740 is associated with non-conducting conformations of the receptor. Neuropharmacology. 2015; 91:34-42. [PubMed: 25497451] 

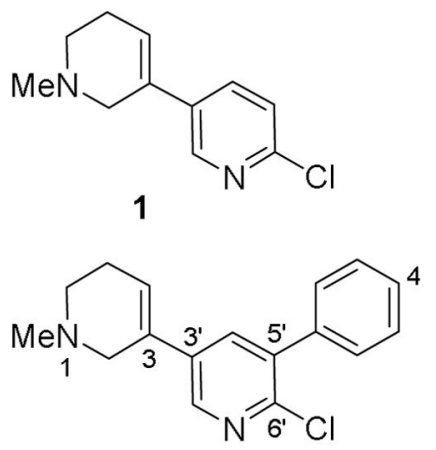

2

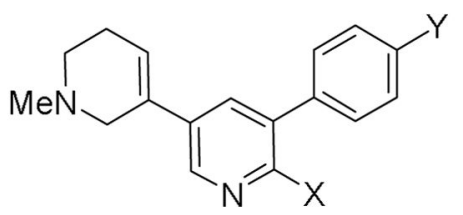

$3 a-3 e$

a: $X=F ; Y=H$

b: $X=F ; Y=F$

c: $X=F ; Y=C l$

d: $X=\mathrm{F} ; \mathrm{Y}=\mathrm{SO}_{2} \mathrm{CH}_{3}$

e: $X=O H ; Y=H$

Figure 1.

Structures of the known nAChR agonist (1) and hypothesized analogues $(\mathbf{2}, \mathbf{3 a}-\mathbf{3 e})$ acting as antagonists. 


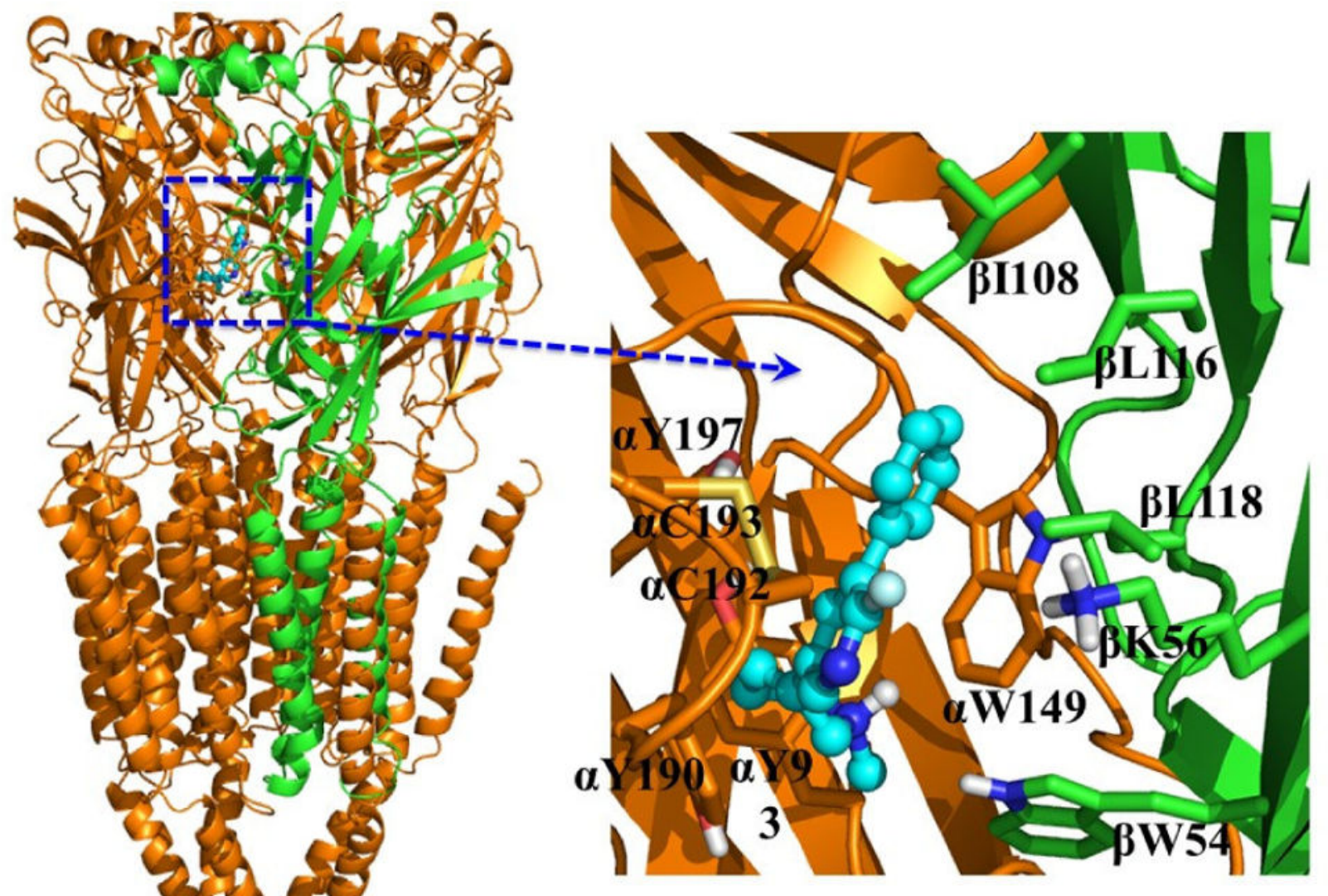

Figure 2.

The modeled structure of compound 3a binding with the closed-channel state of a $3 \beta 4$ nAChR. Left panel: The protein is represented in colored ribbon, with one $\beta 4$ subunit in green, and compound 3a is in ball-stand-stick style with cyan color. Right panel: the details of intermolecular interactions. Amino acid residues of the protein are represented in sticks and are colored by atom types. 


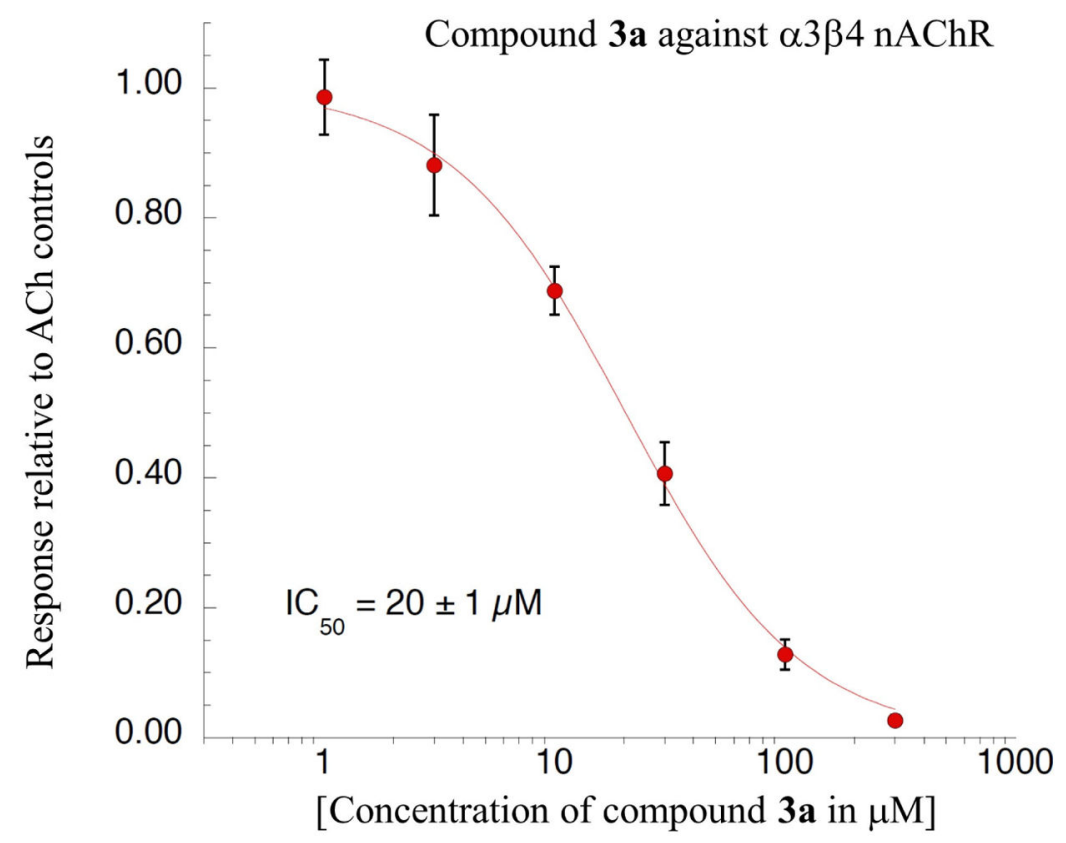

Figure 3.

Dose-dependent antagonism of compound 3a against a $3 \beta 4$ nAChR with $100 \mu \mathrm{M}$ ACh. 


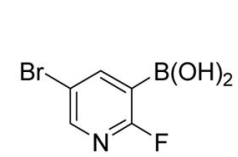

4

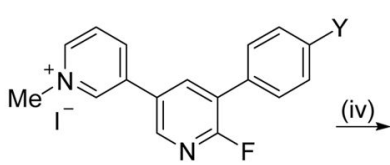

7a- $7 d$

$\stackrel{\text { (iv) }}{\longrightarrow}$

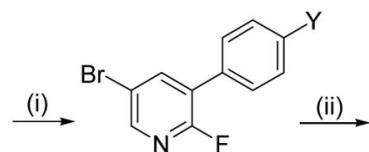

$5 a-5 d$

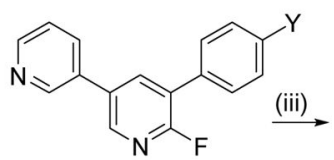

$6 a-6 d$

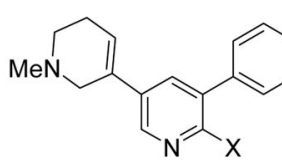

$3 a-3 d$

a: $X=F ; Y=H$

b: $X=F ; Y=F$

c: $X=F ; Y=C l$

d: $X=F ; Y=\mathrm{SO}_{2} \mathrm{Me}$

e: $X=O H ; Y=H($ step $v)$

\section{Scheme 1.}

Synthesis of $5^{\prime}$-phenyl-1,2,5,6-tetrahydro-3,3' -bipyridine analogues (3a- 3e). (i) 4-Y-Ph-Z $(\mathrm{Z}=\mathrm{Br}, \mathrm{I}), \mathrm{Pd}\left(\mathrm{PPh}_{3}\right)_{4}, \mathrm{Na}_{2} \mathrm{CO}_{3}$, aq. $p$-dioxane, $90{ }^{\circ} \mathrm{C}(16-37 \%$ yield); (ii) Pyridine-3boronic acid, $\mathrm{Pd}\left(\mathrm{PPh}_{3}\right)_{4}, \mathrm{Na}_{2} \mathrm{CO}_{3}$, aq. $p$-dioxane, $90{ }^{\circ} \mathrm{C}$ (71-93\% yield); (iii) $\mathrm{MeI}$, acetone, $\mathrm{rt}\left(72-100 \%\right.$ yield); (iv) $\mathrm{NaBH}_{4}$, EtOH, $0{ }^{\circ} \mathrm{C}-\mathrm{rt}$ (35-85\% yield); (v) for 3a to 3e, conc. $\mathrm{HCl}$, aq. $p$-dioxane, $75^{\circ} \mathrm{C}$ (53\% yield). See Supplemental Materials for experimental details. 


\section{Table 1}

Calculated Physico Chemical Properties of 1, 2, and 3a-3e

\begin{tabular}{|l|l|l|l|l|}
\hline Compd ID & Mol. Wt. & Log $^{\boldsymbol{a}}$ & TPSA $^{\boldsymbol{a}}$ & $\operatorname{logBB}^{\boldsymbol{b}}$ \\
\hline nicotine & 162.2 & 1.02 & 16.13 & 0.06 \\
\hline epibatidine & 208.7 & 1.78 & 24.92 & 0.04 \\
\hline $\mathbf{1}$ & 208.7 & 2.13 & 16.13 & 0.22 \\
\hline $\mathbf{2}$ & 284.8 & 3.81 & 16.13 & 0.48 \\
\hline 3a & 268.3 & 3.52 & 16.13 & 0.44 \\
\hline 3b & 286.3 & 3.66 & 16.13 & 0.46 \\
\hline 3c & 302.8 & 4.04 & 16.13 & 0.51 \\
\hline 3d & 346.4 & 2.29 & $58.65(50.27)^{c}$ & $-0.38(-0.26)^{c}$ \\
\hline 3e & 266.3 & 2.08 & 32.34 & -0.02 \\
\hline
\end{tabular}

${ }^{a}$ ChemAxon Calculator Plugins, Marvin 16.8.8, 2016.

$b_{\operatorname{logBB}}=-0.0148 \times$ TPSA $+0.152 \times \log \mathrm{P}+0.139 .[31]$

${ }^{c}$ Excludes sulfur from calculation. 